\title{
High Impact IS Papers and Researchers in the Pacific Asia Region
}

\author{
Shin-Yuan Hung \\ Department of Information Management \\ National Chung Cheng University \\ Chia-Yi, Taiwan \\ syhung@mis.ccu.edu.tw \\ Wei-Hsi Hung \\ Department of Information Management \\ National Chung Cheng University \\ Chia-Yi, Taiwan \\ fhung@mis.ccu.edu.tw \\ Tsan-Ching Kang \\ Department of Information Management \\ National Chung Cheng University \\ Chia-Yi, Taiwan \\ tc.kang@gmail.com \\ King-Zoo Tang \\ Department of Information Management \\ National Chung Cheng University \\ Chia-Yi, Taiwan \\ kingzoo.tang@gmail.com
}

\begin{abstract}
As research in information systems (IS) becomes increasingly popular, it is interesting to know the impact of research from the Pacific Asia region and who has contributed more high impact papers. With the assistance of SSCI/SCIE database of Web of Science and Google Scholar, this study investigates the impact of Pacific Asian researchers and their papers by the citation numbers of their published papers in 21 IS journals. Common keywords and theories adopted in the most cited papers are also examined. The result indicates that scholars in Hong Kong, Australia, and Singapore are major contributors in the region. MIS Quarterly publishes most highly cited papers. Papers co-authored across regions are more likely to create high citations. Our findings provide insights into how research reports from Pacific Asian authors have influenced the development of knowledge in information systems.
\end{abstract}

Keywords: Citation analysis, research impact, research productivity, Pacific Asia region. 


\section{Introduction}

Information system (IS) is a relatively young discipline compared to traditional scientific fields, such as philosophy and physics. Contributions of various types of research are often under debates (such as the debate on design science or IT artifacts). There are many different ways in how to measure the contributions of a scientific research, one of which is citation analysis. Some studies that analyze individual or institutional productivity and the impact of journals have been published in the IS discipline to shed the light for future disciplinary development and provide a "reflective analysis" (Hirschheim and Klein, 2003). Most of these studies are carried out from a global perspective. Undoubtedly, they provide a valuable contribution to the field's development from a holistic view. However, as the discipline is still dominated by scholars in North America, their findings often reveal little insight about researchers in the Pacific Asia region.

The rapid growth of the four "little dragons" in late 20th century followed by China and India in early 21st century has made the Pacific Asia region an important part of the world. Because of the uniqueness and distinctiveness of its culture, the Pacific Asia region is gradually becoming more attractive for IS researchers to investigate the current status of its academic development. In 2007, Communications of the Association for Information Systems (CAIS) had published a special issue presenting the state of the IS academic discipline in Pacific Asia, covering Australia, Hong Kong, Korea, New Zealand, Singapore, and Taiwan. While these articles have covered the development of the area in related countries, it would be useful to explore the influences of research output from authors in the region.

The purpose of this paper is to show the profile of how research in Pacific Asia contributes to the development of knowledge in IS. There are many ways in which the contribution of a research can be evaluated. A quantitative approach that has been widely adopted is citation analysis, which is performed by examining how many times a given published article has been cited by other articles (Lowry et al., 2007). The underlying assumption of this approach is that authors of published papers only cite previous works that they feel useful to support their research. Although this may not be a perfect method, it gains popularity because the computerized citation databases make the recording and calculation possible. This type of study provides a relatively objective way of measuring and analyzing the impact made by academic publication (e.g. journals and research articles).

In this research, we used citation data in the Web of Science (WOS) database and Google Scholars to find the most cited papers and authors in the region. It is hoped that our findings can provide knowledge for a better understanding of the impact of Pacific Asian researchers and point out some directions for future development of IS discipline in the region.

\section{Previous Citation Analysis Studies}

Investigating influential papers has a long history in the IS area. An early work by Hamilton and Ives published in 1982 identified 15 most cited papers with AcKoff's Management Misinformation Systems on the top (Hamilton and Ives, 1982). These highly cited papers were also popular materials for IS courses at that time. In order to determine so called "classic" publications, Culnan (1986, 1987) conducted two citation analysis studies in a variety of time ranges later. The first covered from 1972 to mid-1982; the second covered from 1980 to mid-1985. The number of citations per year was determined by dividing the total number of citations identified from the study period. The screening criterion for classic publications was four or more citations a year on average. In a comparison, Culnan's first study (Culnan, 1986) found seven publications while the second study (Culnan, 1987) identified 13 that meet the criterion of four or more citations a year. This 
comparison shows that more classic (or high impact) publications were found in more recent time period.

Walstrom and Leonard (2000) continued from Culnan's second paper (Culnan, 1987), and picked up the period from 1986 to 1995. They also highlighted publications which averaged at least four citations per year or at least 40 total citations in ten years. More than that, they strictly tagged those papers that belong to so called "super classic". Walstrom and Leonard (2000) believed that the super classic papers, rather than being the phenomenon of well-known papers for a period and then being considered obsolescent after a decade, must remain classic over time. They combined their results with the findings from Culnan's two previous papers (Culnan, 1986, 1987) to identify 91 publications and 13 super classic publications.

In a recent work, Lowry et al. (2007) argued that only a few of previous citation analysis studies have examined the issues of institutional productivity, individual research productivity, or the impact of particular articles. To conduct citation analysis, they chose IS articles from three leading journals: MIS Quarterly (MISQ), Information Systems Research (ISR), and Management Science (MS), in order to determine the institutions, individuals, articles, and themes that have had the greatest impact on the IS field. Their results supplied several interesting findings. First, the leading productive institutions have changed over time, and institutions outside of North America are poorly represented. Second, no institution had consistent impact across all three journals. Third, clear differences in the journals' publication patterns emerge. ISR has been more likely to publish e-commerce-related articles, while MISQ has been much more likely to publish on knowledge management and management of IS. The group support systems (GSS) issue has been a larger portion of publications in both MISQ and ISR than in MS.

By using different data sources, Whitley and
Galliers (2007) utilized the papers published in European Conference on IS (ECIS) to study the citation preferences in the European academic environment. They claimed that using ECIS as a data source provides a wider and more international perspective to analyze current topics with short time lag. Different from previous citation analysis studies, the results showed that extensive classic citations in the sample papers were books, and papers from the Harvard Business Review (HBR) and the Sloan Management Review (SMR). Moreover, Whitley and Galliers (2007) found that social theorists are more widely cited in European IS research than in the North American studies. ECIS authors are more inclined to use both US and European sources than authors in North American journals. These findings indicate that citations (or impacts) may have different patterns in different geographical regions. To our knowledge so far, no research on the impact of Pacific Asian authors has been published. Therefore, it would be interesting to explore the citation profile of authors in this region, as the culture of many countries in this region is different from that in Europe and in the United States.

\section{Method}

The research includes two main steps. First, major IS journals were selected to identify publications from Pacific Asian authors. The citations of these journal papers in the SSCI/SCIE (Social Science Citation Index I Science Citation Index Expanded) database of Web of Science (WOS) were then retrieved and analyzed. We chose journals for study based on the journal list suggested by Liang (2004) in terms of most elite IS journals. CAIS was excluded from our study because its citation data was not included in the WOS database. Management Science and Decision Sciences were added into the list for their reputation in the IS field. The final list contains 21 journals: Communications of the ACM (CACM), DATA BASE for Advances in Information Systems, Decision Sciences (DS), Decision Support Systems (DSS), European Journal of Information Systems (EJIS), Expert 
High Impact IS Papers and Researchers /Hung et al.

Systems with Applications (ESWA), Information and Management (I\&M), International Journal of Electronic Commerce (IJEC), International Journal of HumanComputer Studies (IJHCS), Information Processing and Management (IPM), INFORMS Journal on Computing, Information Systems Journal (ISJ), Information Systems Research (ISR), Journal of the Association for Information Systems (JAIS), Journal of Computer Information Systems (JCIS), Journal of Information Technology (JIT), Journal of Management Information Systems (JMIS), Journal of Organization Computing and Electronic Commerce (JOCEC), Journal of Strategic Information Systems (JSIS), MIS Quarterly (MISQ), and Management Sciences (MS). This is a pretty complete list of journals that covers most major IS papers.

The authors residing in the Pacific Asia region and having papers published in these 21 journals from 1956 to October 2008 were identified and compiled into an author list. For those authors who moved to different regions during the period, we assigned all of their papers into the total publication list of the region that they permanently reside in. Editorial material, notes, and letter types were excluded and only full research papers were retained. After identifying the authors and their papers, the researchers examined the nature of each paper to see whether they are IS papers in a series of discussion sessions. A list of candidate papers was compiled.

Two sets of citation data were used in our analysis: the SSCI/SCIE database of WOS and Google Scholar. WOS is a commercial product offered by Thomson Reuters, which covers more than 1700 different journals in social sciences and more than 6000 journals in sciences and engineering. The citation data in the SSCI/SCIE database is derived from papers published in journals that were included in the database's journal lists. These journals are often more rigorous in their respective disciplines. Because the SSCI/SCIE database has its own criteria of selection, the database only collects those issues and articles afterward the time that the journal has been included in the SSCI/SCIE database. Furthermore, it may exclude some issues or articles in certain journals from time to time. For example, the database only includes the articles in JMIS after 1999 (Volume16, Issue2) despite the journal's inaugural publication was in 1984. Google scholar is an online database maintained by Google (http://scholar.google.com/). Its citation data were primarily collected from the Internet and hence may include more diverse sources, including conference papers and working papers.

Since the SSCI/SCIE database often indicates citations in quality journals, we first search the database to find the total citation number for each paper in the final paper list of papers from Pacific Asian authors. We set the time range of the SSCI/SCIE database from 1956 to 2008 to cover, as mentioned previously, certain articles in the 21 journals that have been included in the database. Papers with total citation number higher than 45 were included in the High Impact Paper List. Considering the reminder given by Clarke (2008), we further searched Google Scholar to find online citations of each paper. These data were then combined to show their total citations.

After the high impact papers were identified, we performed a series of analysis to find the frequently-used keywords and theories among the highly cited papers. For the keyword analysis, we compiled a list of keywords supplied by the papers. These keywords were analyzed by their occurrence frequency and those appeared more than twice were marked as popular keywords. Another issue we analyzed was the popularity of different theories adopted in the highly cited papers. Theories adopted in more than two papers are marked as popular theories.

In addition to identifying the highly cited papers, we also calculated the total citation number in the SSCI/SCIE database for each author from the Pacific Asia to find their individual impacts. Since Google Scholar does not provide a convenient tool for 
analyzing individual author's citations, we only analyze the citation data in the WOS database. Authors with total citation number higher than 100 were shown in the Most Cited Author List.

\section{Findings and Discussions}

\section{Highly Cited Papers from Pacific Asian Authors}

Following the procedures described in the previous section, we have found 39 papers in 21 journals that each of which was cited more than 45 times in the SSCI/SCIE database of WOS. Appendix 1 shows their citation frequencies, authors, paper title, and publishing journals. Authors in the Pacific Asia region are printed in bold and underlined in the table.

It turns out the paper by Nunamaker, Dennis, Valacich, Vogel, and George in 1991 published in Communications of the ACM has the highest WOS and Google Scholar citation numbers. Klein and Myers (1999) in MIS Quarterly has the second total citation numbers over a thousand, although Tam and Kiang (1992) in Management Science has a slightly higher citation frequency in WOS. Nine papers have total citation frequencies higher than 500 . There are 10 of them that have WOS citation frequencies higher than 100, 33 of them higher than 50.

Among the 39 most cited papers, 29 were published prior to 2000, while 10 were published after 2000 (including 2000). This indicates that time is a critical factor for having impact. The earliest papers are Tait and Vessey's (1988) "The Effect of User Involvement on System Success - a Contingency Approach" which appeared in MISQ and Rivard and Huff's (1988) "Factors of Success for End-User Computing" which appeared in CACM, and they are followed by Dennis, George, Jessup, Nunamaker, and Vogel's (1988) "Information Technology to Support Electronic Meetings" which also appeared in MISQ. The latest one also appeared in MISQ, that is, Bock, Zmud, Kim, and Lee's (2005) "Behavioral Intention Formation in Knowledge Sharing: Examining the Roles of Extrinsic Motivators, SocialPsychological Forces, and Organizational Climate."

Analyzing the publication outlets of these highly cited papers, we find that 13 of them appeared in MISQ; seven in CACM; five each in I\&M and $M S$; three each in $D S$ and $I S R$; and one each in JMIS, DSS, and IJEC. Among those highly cited papers, 12 have all co-authors in the Pacific Asia region and 27 have mixed authorship outside the region. This indicates that cross region authorship may have an advantage in creating more impact for Pacific Asian authors. Four authors have participated in the authorship of three or more of them: Patrick Y.K. Chau (4 papers), Douglas. R. Vogel (3 papers), Kar Yan Tam (3 papers), Paul B. Cragg (3 papers), and Young Gul Kim (3 papers).

Table 1 shows popular keywords found in the most cited papers. Any keyword that is referred more than twice is included. Among the 12 keywords in the table, the keywords "technology acceptance and adoption" appeared 13 times to be the top. This, along with the top rank of technology acceptance model (TAM) in Table 2, shows that technology acceptance has been a dominating topic in the past years. The second frequently used keywords are "case study" and "small business", which appeared only four times each. Except technology acceptance, other key words are quite diverse. This also reflects the diversity of the IS field.

Table 2 lists the theories which had been adopted in the highly cited papers twice or more. The most popular theory is technology acceptance model, followed by InputProcess-Output model and the transaction cost theory. Four theories ranked forth have the same frequency of use: cognitive fit theory, diffusion of innovations, institutional theory, and IS success model. 


Table 1. Popular Keywords in the Most Cited Papers
\begin{tabular}{|c|l|c|}
\hline \multicolumn{1}{|c|}{ Keywords } & Frequency \\
\hline $\mathbf{1}$ & Technology acceptance and adoption & 13 \\
\hline $\mathbf{2}$ & Case study & 4 \\
\hline $\mathbf{2}$ & Small business & 4 \\
\hline $\mathbf{4}$ & IS success & 3 \\
\hline $\mathbf{4}$ & IT infrastructure & 3 \\
\hline $\mathbf{6}$ & E-commerce & 2 \\
\hline $\mathbf{6}$ & Electronic meeting systems/Group support systems & 2 \\
\hline $\mathbf{6}$ & IS research methodologies & 2 \\
\hline $\mathbf{6}$ & Information technology & 2 \\
\hline $\mathbf{6}$ & Neural networks & 2 \\
\hline $\mathbf{6}$ & Structural equation models & 2 \\
\hline $\mathbf{6}$ & Transaction cost theory & 2 \\
\hline
\end{tabular}

\section{Table 2. Common Theories in the Most Cited Papers}

\begin{tabular}{|c|l|c|}
\hline Rank & \multicolumn{1}{|c|}{ Theory } & Times Used \\
\hline $\mathbf{1}$ & Technology acceptance model & 4 \\
\hline $\mathbf{2}$ & Input-Process-Output model & 3 \\
\hline $\mathbf{2}$ & Transaction cost theory & 3 \\
\hline $\mathbf{4}$ & Cognitive fit theory & 2 \\
\hline $\mathbf{4}$ & Diffusion of innovations & 2 \\
\hline $\mathbf{4}$ & Institutional theory & 2 \\
\hline $\mathbf{4}$ & IS success model & 2 \\
\hline
\end{tabular}

\section{Highly Cited Authors in the Pacific Asia}

Table 3 presents the authors in Pacific Asia whose papers published in the 21 journals have been cited more than 100 times totally in the WOS database. The year of aggregation is from 1956 to 2008.

As shown in Table 3, 10 authors have received more than 300 citations of their works. Douglas R. Vogel is in the top position with a citation of 809 times. He is followed by Iris Vessey (716 times), Kar Yan Tam (615 times) and Patrick Y.K. Chau (549 times). Douglas R. Vogel, Iris Vessey and Kar Yan Tam are three authors whose papers have been cited more than 600 times.

Table 4 shows the geographical distribution of those highly cited authors. Among those most cited authors, 10 of them are in Hong Kong; seven each in Australia and Singapore; five in Korea; three in New Zealand; two in Taiwan; and one in China. When looking at the institutions of those most cited authors (Table 5), six institutions have at least two most cited authors. City University of Hong Kong has six authors, and National University of Singapore have five authors, while Korea Advanced Institute of Science and Technology has three authors. Hong Kong University of Science and Technology, Monash University, and Nanyang Technological University, each has two authors. The most cited authors in Singapore are mainly affiliated with National University of Singapore (with 5 authors), while six of the 10 of the most cited authors in Hong Kong are affiliated with the City University of Hong Kong. 


\section{Table 3. Most Cited Author List in Pacific Asia in terms of the $\mathbf{2 1}$ journals}

\begin{tabular}{|c|c|c|c|}
\hline Rank & Researcher & University & Citation $^{a}$ \\
\hline 1 & Vogel, Douglas. R. & City University of Hong Kong (HK) & 809 \\
\hline 2 & Vessey, Iris & University of Queensland (AU) & 716 \\
\hline 3 & Tam, Kar Yan & Hong Kong University of Science and Technology (HK) & 615 \\
\hline 4 & Chau, Patrick Y.K. & The University of Hong Kong (HK) & 549 \\
\hline 5 & Huff, Sid L. & Victoria University of Wellington (NZ) & 487 \\
\hline 6 & Wei, Kwok-Kee & City University of Hong Kong (HK) & 444 \\
\hline 7 & Kim, Young Gul & Korea Advanced Institute of Science and Technology (KR) & 383 \\
\hline 8 & Liang, Ting-Peng & National Sun Yat-Sen University (TW) & 307 \\
\hline 9 & Myers, Michael D. & University of Auckland (NZ) & 305 \\
\hline 10 & Cragg, Paul B. & University of Canterbury (NZ) & 300 \\
\hline 11 & Weber, Ron & Monash University (AU) & 297 \\
\hline 12 & Han, Ingoo & Korea Advanced Institute of Science and Technology (KR) & 294 \\
\hline 13 & Tan, Bernard C.Y. & National University of Singapore (SG) & 259 \\
\hline 14 & Teo, Thompson S.H. & National University of Singapore (SG) & 228 \\
\hline 15 & Yap, Chee-Sing & National University of Singapore (SG) & 220 \\
\hline 16 & Cavaye, Angèle L.M. & Flinders University (AU) & 209 \\
\hline 17 & Raman, Krishnamurthy S. & National University of Singapore (SG) & 205 \\
\hline 17 & Thong, James Y.L. & Hong Kong University of Science and Technology (HK) & 185 \\
\hline 19 & Lee, Jae Kyu & Korea Advanced Institute of Science and Technology (KR) & 173 \\
\hline 20 & Seddon, Peter B. & The University of Melbourne (AU) & 173 \\
\hline 21 & Lee, Kun Chang & Sungkyunkwan University (KR) & 171 \\
\hline 22 & Zhuge, Hai & Chinese Academy of Sciences (CN) & 168 \\
\hline 23 & Ang, Soon & Nanyang Technological University (SG) & 165 \\
\hline 24 & Lee, Jae-Nam & Korea University Business School (KR) & 158 \\
\hline 25 & Lee, Matthew K.O. & City University of Hong Kong (HK) & 126 \\
\hline 26 & Lai, Vincent S. & The Chinese University of Hong Kong (HK) & 122 \\
\hline 26 & Davison, Robert M. & City University of Hong Kong (HK) & 118 \\
\hline 28 & Wang, Huaiqing & City University of Hong Kong (HK) & 118 \\
\hline 29 & Shanks, Graeme & Monash University (AU) & 114 \\
\hline 29 & Glass, Robert L. & Griffith University (AU) & 112 \\
\hline 31 & Love, Peter E.D. & Edith Cowan University (AU) & 112 \\
\hline 31 & Martinsons, Maris G. & City University of Hong Kong (HK) & 108 \\
\hline 33 & Soh, Christina & Nanyang Technological University (SG) & 108 \\
\hline 34 & Teo, Hock-Hai & National University of Singapore (SG) & 101 \\
\hline 35 & Wang, Eric T.G. & National Central University (TW) & 100 \\
\hline
\end{tabular}

${ }^{a}$ : Retrieved from 1956 to October 2008 


\begin{tabular}{|c|l|c|}
\hline \multicolumn{3}{|c|}{ Table 4: Geographical Distribution of Highly Cited Authors } \\
\hline Rank & Countries/Areas & Frequency \\
\hline $\mathbf{1}$ & Hong Kong & 10 \\
\hline $\mathbf{2}$ & Australia & 7 \\
\hline $\mathbf{2}$ & Singapore & 7 \\
\hline $\mathbf{4}$ & Korea & 5 \\
\hline $\mathbf{5}$ & New Zealand & 3 \\
\hline $\mathbf{6}$ & Taiwan & 2 \\
\hline $\mathbf{7}$ & China & 1 \\
\hline
\end{tabular}

\section{Table 5: Affiliation Distribution of Highly Cited Authors}

\begin{tabular}{|c|l|c|}
\hline Rank & \multicolumn{1}{|c|}{ University } & Frequency \\
\hline $\mathbf{1}$ & City University of Hong Kong & 6 \\
\hline $\mathbf{1}$ & National University of Singapore & 5 \\
\hline $\mathbf{3}$ & Korea Advanced Institute of Science and Technology & 3 \\
\hline $\mathbf{4}$ & Hong Kong University of Science and Technology & 2 \\
\hline $\mathbf{4}$ & Monash University & 2 \\
\hline $\mathbf{4}$ & Nanyang Technological University & 2 \\
\hline
\end{tabular}

\section{Conclusion}

This study has examined the impact of Pacific Asia researchers by looking at the citation numbers of their published papers in 21 major IS journals. The results show that MISQ published most highly cited papers by Pacific Asian authors. Those papers included in our list represent the ones that have been cited more than 45 times. Among the authors of most cited papers, Douglas R. Vogel, Iris Vessey and Kar Yan Tam are the only three authors whose papers have been cited more than 600 times. Technology acceptance and adoption and technology acceptance model are most popular keywords and theories among the most cited papers respectively. Furthermore, Hong Kong, Australia, and Singapore produce most highly cited authors. National University of Singapore and City University of Hong Kong have more highly cited authors than other universities. As the IS field is continuously evolving, the results of our citation analysis may be useful to shed the light of contemporary interests in IS field.

The findings from this study reveal some interesting insights about the profile of high impact papers from Pacific Asian authors in major IS journals. However, it has several limitations. First, only 21 major IS journals were selected in our study. There may be high impact IS papers from Pacific Asian authors published in other journals outside the coverage of this research. Although we have tried to incorporate as many IS journals as possible, we could only cover major ones and especially those included in the WOS database at that time. Second, we could only access citation records of the papers in the SSCI/SCIE database of WOS, and consequently papers outside the database were excluded in this study, such as the papers of JMIS prior to 1999, papers of MISQ prior to 1984, papers of JAIS prior to 2007, etc. This may lead to underestimation of the citation numbers for authors. Third, we calculated the contribution of each of authors in a paper equally regardless his or her priority in the author list. In this way, we cannot differentiate their contributions. Forth, researchers might miss out one initial or add the initial of his or her nickname. This would cause the problem of calculating the total 
citation number for the author. Although we have tried to search all possible combinations, there were still some rooms for oversights. Finally, our findings from data in the past may not be valuable for predicting future IS trends. Certain new

\section{References}

Clarke, R. (2008) "An Exploratory Study of Information Systems Researcher Impact", Communications of the Association for Information Systems 22 (1), pp.1-32.

Culnan, M. J. (1986) "The Intellectual Development of Management Information Systems, 1972-1982: A Co-Citation Analysis," Management Science 32 (2), pp.156-172.

Culnan, M. J. (1987) "Mapping the Intellectual Structure of MIS, 19801985: A Co-Citation Analysis", MIS Quarterly 11 (3), pp.341-353.

Hamilton, S. and Ives, B. (1982), "Knowledge Utilization Among MIS Researchers, MIS Quarterly 6 (4), p61-77.

Hirschheim, R., and Klein, H. K. (2003). "Crisis in the IS Field? A Critical Reflection on the State of the Discipline", Journal of the Association for Information Systems, 4 (5), pp.237-293. journals that may become major ones in the future were not included in our analysis list. This could result in biases. Therefore, our results should be interpreted carefully with the limitations in mind.

Liang, T.P. (2004) "Ranking Journals in Information Systems Research, "Research Project Report (NSC 922416-H-110-005), National Science Council, Taiwan (in Chinese).

Lowry, P. B., Karuga, G. G., and Richardson, V. J. (2007) "Assessing Leading Institutions, Faculty, and Articles in Premier Information Systems Research Journals", Communications of the Association for Information Systems 20 (16), pp.142-203.

Walstrom, K. A., and Leonard, L. N. K. (2000) "Citation Classics from the Information Systems Literature", Information and Management 38 (2), pp.59-72.

Whitley, E. A., and Galliers, R. D. 2007. "An Alternative Perspective on Citation Classics: Evidence from the First 10 Years of the European Conference on Information Systems", Information and Management 44 (5), pp.441-455. 


\section{Appendix 1: Most Cited Papers in the Pacific Asia in the 21 journals}

\begin{tabular}{|c|c|c|c|c|c|c|c|}
\hline Rank & Researcher & $\begin{array}{l}\text { Total } \\
\text { Citation }\end{array}$ & $\begin{array}{c}\text { WOS } \\
\text { Citation }^{a}\end{array}$ & $\begin{array}{c}\text { Google } \\
\text { Scholar } \\
\text { Citation }^{b} \\
\end{array}$ & Journal & Title & Year \\
\hline 1 & $\begin{array}{l}\text { Nunamaker, J.F.; } \\
\text { Dennis, A.R.; } \\
\text { Valacich, J.S.; } \\
\text { Vogel, Douglas. R.; } \\
\text { George, J.F. }\end{array}$ & 1428 & 364 & 1064 & $\begin{array}{l}\text { Communications of the } \\
\text { ACM }\end{array}$ & Electronic Meeting Systems to Support Group Work & 1991 \\
\hline 2 & $\begin{array}{l}\text { Klein, H.K.; } \\
\text { Myers, Michael D. }\end{array}$ & 1226 & 198 & 1028 & MIS Quarterly & $\begin{array}{l}\text { A Set of Principles for Conducting and Evaluating } \\
\text { Interpretive Field Studies in Information Systems }\end{array}$ & 1999 \\
\hline 3 & $\frac{\text { Tam, Kar Yan; }}{\text { Kiang, M.Y. }}$ & 661 & 199 & 462 & Management Science & $\begin{array}{l}\text { Managerial Applications of Neural Networks - the Case of } \\
\text { Bank Failure Predictions }\end{array}$ & 1992 \\
\hline 4 & $\begin{array}{l}\text { Dennis, A.R.; } \\
\text { George, J.F.; } \\
\text { Jessup, L.M.; } \\
\text { Nunamaker, J.F.; } \\
\text { Vogel, Douglas. R.; }\end{array}$ & 628 & 231 & 397 & MIS Quarterly & Information Technology to Support Electronic Meetings & 1988 \\
\hline 5 & $\begin{array}{l}\text { Hevner, A.R.; } \\
\text { March, S.T.; } \\
\text { Park, Jinsoo }\end{array}$ & 573 & 83 & 490 & MIS Quarterly & Design Science in Information Systems Research & 2004 \\
\hline 6 & $\begin{array}{l}\text { Compeau, D.; } \\
\text { Higgins, C.A.; } \\
\text { Sid L. Huff } \\
\end{array}$ & 567 & 168 & 399 & MIS Quarterly & $\begin{array}{l}\text { Social Cognitive Theory and Individual Reactions to } \\
\text { Computing Technology: A Longitudinal Study }\end{array}$ & 1999 \\
\hline 7 & $\begin{array}{l}\text { Igbaria, M.; } \\
\text { Zinatelli, N.; } \\
\text { Cragg, Paul B.; } \\
\text { Cavaye, A.L.M. } \\
\end{array}$ & 561 & 144 & 417 & MIS Quarterly & $\begin{array}{l}\text { Personal Computing Acceptance Factors in Small Firms: } \\
\text { A Structural Equation Model }\end{array}$ & 1997 \\
\hline
\end{tabular}




\begin{tabular}{|c|c|c|c|c|c|c|c|}
\hline 8 & $\begin{array}{l}\text { Moon, Ji-Won; } \\
\text { Kim, Young Gul }\end{array}$ & 539 & 121 & 418 & $\begin{array}{l}\text { Information and } \\
\text { Management }\end{array}$ & Extending the TAM for a World-Wide-Web Context & 2001 \\
\hline 9 & Seddon, Peter B. & 513 & 132 & 381 & $\begin{array}{l}\text { Information Systems } \\
\text { Research }\end{array}$ & $\begin{array}{l}\text { A Respecification and Extension of the DeLone and } \\
\text { McLean Model of IS Success }\end{array}$ & 1997 \\
\hline 10 & $\begin{array}{l}\text { Hu, P.J.H.; } \\
\text { Chau, Patrick Y.K.; } \\
\text { Sheng, O.R.L.; } \\
\text { Tam, Kar Yan; }\end{array}$ & 433 & 118 & 315 & $\begin{array}{l}\text { Journal of Management } \\
\text { Information Systems }\end{array}$ & $\begin{array}{l}\text { Examining the Technology Acceptance Model Using } \\
\text { Physician Acceptance of Telemedicine Technology }\end{array}$ & 1999 \\
\hline 11 & $\underline{\text { Vessey, Iris }}$ & 422 & 140 & 282 & Decision Sciences & $\begin{array}{l}\text { Cognitive Fit: A Theory-Based Analysis of the Graphs } \\
\text { Versus Tables Literature }\end{array}$ & 1991 \\
\hline 12 & $\begin{array}{l}\text { Soh, Christina; } \\
\text { Kien, Sia Siew; } \\
\text { Tay-Yap, Joanne } \\
\end{array}$ & 414 & 97 & 317 & $\begin{array}{l}\text { Communications of the } \\
\text { ACM }\end{array}$ & Cultural Fits and Misfits: Is ERP a Universal Solution? & 2000 \\
\hline 13 & Lee, Ho-Geun & 406 & 50 & 356 & $\begin{array}{l}\text { Communications of the } \\
\text { ACM }\end{array}$ & Do Electronic Marketplaces Lower the Price of Goods? & 1998 \\
\hline 14 & $\begin{array}{l}\text { Avison, D; } \\
\text { Lau, F; } \\
\text { Myers, Michael D.; } \\
\text { Nielsen, P.A. }\end{array}$ & 392 & 65 & 327 & $\begin{array}{l}\text { Communications of the } \\
\text { ACM }\end{array}$ & Action Research & 1999 \\
\hline 15 & $\frac{\text { Cragg, Paul B.; }}{\text { King, M. }}$ & 387 & 81 & 306 & MIS Quarterly & Small-Firm Computing - Motivators and Inhibitors & 1993 \\
\hline 16 & $\begin{array}{l}\text { Hong, Kyung-Kwon; } \\
\text { Kim, Young Gul }\end{array}$ & 367 & 84 & 283 & $\begin{array}{l}\text { Information and } \\
\text { Management }\end{array}$ & $\begin{array}{l}\text { The Critical Success Factors for ERP Implementation: An } \\
\text { Organizational Fit Perspective }\end{array}$ & 2002 \\
\hline 17 & $\begin{array}{l}\text { Lee, Matthew K.O.; } \\
\text { Turban, E. }\end{array}$ & 359 & 62 & 297 & $\begin{array}{l}\text { International Journal of } \\
\text { Electronic Commerce }\end{array}$ & A Trust Model for Consumer Internet Shopping & 2001 \\
\hline
\end{tabular}




\begin{tabular}{|c|c|c|c|c|c|c|c|}
\hline 18 & $\begin{array}{l}\text { King, J.L.; } \\
\text { Gurbaxani, V.; } \\
\text { Kraemer, K.L.; } \\
\text { McFarlan F.W.; } \\
\frac{\text { Raman, }}{\text { Krishnamurthy S.; }} \\
\text { Yap, Chee-Sing }\end{array}$ & 320 & 74 & 246 & $\begin{array}{l}\text { Information } \\
\text { Research }\end{array}$ & Institutional Factors in Information Technology Innovation & 1994 \\
\hline 19 & $\begin{array}{l}\text { Poon, Simpson; } \\
\text { Swatman, Paula M.C. }\end{array}$ & 308 & 46 & 262 & $\begin{array}{ll}\text { Information } & \text { and } \\
\text { Management } & \end{array}$ & $\begin{array}{l}\text { An Exploratory Study of Small Business Internet } \\
\text { Commerce Issues }\end{array}$ & 1999 \\
\hline 20 & $\frac{\text { Ang, Soon; }}{\text { Straub, DW }}$ & 300 & 60 & 240 & MIS Quarterly & $\begin{array}{l}\text { Production and Transaction Economies and IS } \\
\text { Outsourcing: A Study of the US Banking Industry }\end{array}$ & 1998 \\
\hline 21 & $\begin{array}{l}\text { Liang, Ting-Peng; } \\
\text { Huang, Jin-Shiang }\end{array}$ & 293 & 59 & 234 & $\begin{array}{l}\text { Decision } \\
\text { Systems }\end{array}$ & $\begin{array}{l}\text { An Empirical Study on Consumer Acceptance of Products } \\
\text { in Electronic Markets: A Transaction Cost Model }\end{array}$ & 1998 \\
\hline 22 & $\begin{array}{l}\text { Tait, Peter; } \\
\text { Vessey, Iris } \\
\end{array}$ & 272 & 91 & 181 & MIS Quarterly & $\begin{array}{l}\text { The Effect of User Involvement on System Success - a } \\
\text { Contingency Approach }\end{array}$ & 1988 \\
\hline 23 & $\begin{array}{l}\text { Broadbent, Marianne; } \\
\text { Weill, Peter; } \\
\text { St. Clair, D. }\end{array}$ & 265 & 53 & 212 & MIS Quarterly & $\begin{array}{l}\text { The Implications of Information Technology Infrastructure } \\
\text { for Business Process Redesign }\end{array}$ & 1999 \\
\hline 24 & $\begin{array}{l}\text { Chau, Patrick Y.K.; } \\
\text { Tam, Kar Yan }\end{array}$ & 261 & 54 & 207 & MIS Quarterly & $\begin{array}{l}\text { Factors Affecting the Adoption of Open Systems: An } \\
\text { Exploratory Study }\end{array}$ & 1997 \\
\hline 25 & $\begin{array}{l}\text { Dewan, S.; } \\
\text { Min, Chung-Ki }\end{array}$ & 258 & 60 & 198 & Management Science & $\begin{array}{l}\text { The Substitution of Information Technology for Other } \\
\text { Factors of Production: A Firm Level Analysis }\end{array}$ & 1997 \\
\hline 26 & $\begin{array}{l}\text { Rivard, S; } \\
\text { Sid L. Huff } \\
\end{array}$ & 252 & 98 & 154 & $\begin{array}{l}\text { Communications of the } \\
\text { ACM }\end{array}$ & Factors of Success for End-User Computing & 1988 \\
\hline 27 & $\begin{array}{l}\text { Bock, Gee-Woo; } \\
\text { Zmud, R.W.; } \\
\text { Kim, Young Gul; } \\
\text { Lee, Jae-Nam }\end{array}$ & 239 & 60 & 179 & MIS Quarterly & $\begin{array}{l}\text { Behavioral Intention Formation in Knowledge Sharing: } \\
\text { Examining the Roles of Extrinsic Motivators, Social- } \\
\text { Psychological Forces, and Organizational Climate }\end{array}$ & 2005 \\
\hline
\end{tabular}




\begin{tabular}{|c|c|c|c|c|c|c|c|}
\hline 28 & $\begin{array}{l}\text { Chau, Patrick Y.K.; } \\
\text { Hu, P.J.H. }\end{array}$ & 230 & 54 & 176 & Decision Sciences & $\begin{array}{l}\text { Information Technology Acceptance by Individual } \\
\text { Professionals: A Model Comparison Approach }\end{array}$ & 2001 \\
\hline 29 & $\begin{array}{l}\text { Wang, Huaiqing; } \\
\text { Lee, Matthew K.O.; }\end{array}$ & 227 & 48 & 179 & $\begin{array}{l}\text { Communications of the } \\
\text { ACM }\end{array}$ & Consumer Privacy Concerns about Internet Marketing & 1998 \\
\hline 30 & $\begin{array}{l}\text { Mehrtens, J; } \\
\text { Cragg, Paul B.; } \\
\text { Mills, Annette M. }\end{array}$ & 218 & 48 & 170 & $\begin{array}{l}\text { Information and } \\
\text { Management }\end{array}$ & A Model of Internet Adoption by SMEs & 2001 \\
\hline 31 & $\begin{array}{l}\text { Nam, Kichan; } \\
\text { Rajagopalan, S; } \\
\text { Rao, HR; } \\
\text { Chaudhury, A. }\end{array}$ & 218 & 47 & 171 & $\begin{array}{l}\text { Communications of the } \\
\text { ACM }\end{array}$ & $\begin{array}{l}\text { A Two-level Investigation of Information Systems } \\
\text { Outsourcing }\end{array}$ & 1996 \\
\hline 32 & $\begin{array}{l}\text { Wang, Eric T.G.; } \\
\text { Seidmann, A }\end{array}$ & 211 & 55 & 156 & Management Science & $\begin{array}{l}\text { Electronic Data Interchange - Competitive Externalities } \\
\text { and Strategic Implementation Policies }\end{array}$ & 1995 \\
\hline 33 & $\begin{array}{l}\text { Nunamaker, J.F.; } \\
\text { Dennis, A.R.; } \\
\text { Valacich, J.S.; } \\
\text { Vogel, Douglas. R. }\end{array}$ & 209 & 64 & 145 & Management Science & $\begin{array}{l}\text { Information Technology for Negotiating Groups - } \\
\text { Generating Options for Mutual Gain }\end{array}$ & 1991 \\
\hline 34 & $\begin{array}{l}\text { Thong, James Y.L; } \\
\text { Yap, Chee-Sing; } \\
\text { Raman, } \\
\text { Krishnamurthy S; }\end{array}$ & 204 & 53 & 151 & $\begin{array}{l}\text { Information Systems } \\
\text { Research }\end{array}$ & $\begin{array}{l}\text { Top Management Support, External Expertise and } \\
\text { Information Systems Implementation in Small Businesses }\end{array}$ & 1996 \\
\hline 35 & $\begin{array}{l}\text { Teo, Hock-Hai; } \\
\text { Wei, Kwok-Kee; } \\
\text { Benbasat, I. }\end{array}$ & 200 & 50 & 150 & MIS Quarterly & $\begin{array}{l}\text { Predicting Intention to Adopt Inter-organizational } \\
\text { Linkages: An Institutional Perspective }\end{array}$ & 2003 \\
\hline 36 & Chau, Patrick Y.K. & 185 & 63 & 122 & Decision Sciences & $\begin{array}{l}\text { Reexamining a Model for Evaluating Information Center } \\
\text { Success Using a Structural Equation Modeling Approach }\end{array}$ & 1997 \\
\hline
\end{tabular}


High Impact IS Papers and Researchers /Hung et al.

\begin{tabular}{|c|c|c|c|c|c|c|c|}
\hline 37 & $\begin{array}{l}\text { Igbaria, M; } \\
\text { Tan, Margaret }\end{array}$ & 180 & 45 & 135 & $\begin{array}{ll}\text { Information } & \text { and } \\
\text { Management } & \\
\end{array}$ & $\begin{array}{l}\text { The Consequences of Information Technology } \\
\text { Acceptance on Subsequent Individual Performance }\end{array}$ & 1997 \\
\hline 38 & $\begin{array}{l}\text { Hill, T.; } \\
\text { O'Connor, Marcus; } \\
\text { Remus, W. }\end{array}$ & 158 & 49 & 109 & Management Science & Neural Network Models for Time Series Forecasts & 1996 \\
\hline 39 & $\begin{array}{l}\text { Keil, M; } \\
\text { Tan, Bernard C.Y.; } \\
\text { Wei, Kwok-Kee; } \\
\text { Tuunainen, V.; } \\
\text { Wassenaar, A. }\end{array}$ & 155 & 53 & 102 & MIS Quarterly & $\begin{array}{l}\text { A Cross-Cultural Study on Escalation of Commitment } \\
\text { Behavior in Software Projects }\end{array}$ & 2000 \\
\hline
\end{tabular}

${ }^{a}$ : Retrieved on October 2008. ${ }^{b}$ : Retrieved on November 2008.

Note: Names in bold are Authors with full-time affiliation with a university in the Pacific Asia region. 


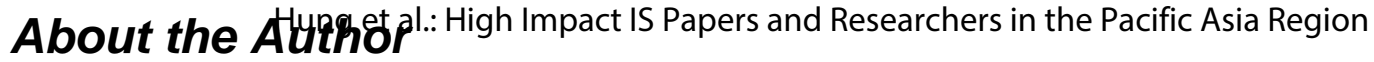

Shin-Yuan Hung is a Professor of Information Systems at National Chung Cheng University in Taiwan. He was a visiting scholar of the MIS Department at the University of Arizona during summer 2007-spring 2008. Prior to the leave, he had been the Secretary General of the same university. Dr. Hung received his bachelor degree in Statistics from the National Chung Hsing University in Taiwan and his master and doctoral degrees in Information Systems from the National Sun Yat-sen University in Taiwan. His current research interests include decision support systems, knowledge management, electronic commerce, and data mining. He has published a number of papers in Decision Support Systems, Information \& Management, Electronic Commerce Research and Applications, Information Technology \& People, Communications of the AIS, Expert Systems with Applications, Government Information Quarterly, Computer Standard and Interfaces, Pacific Asian Journal of Association for Information Systems, Journal of Chinese Information Management, among others.
Wei-Hsi Hung is an Assistant Professor of Information Management at National Chung Cheng University, Taiwan. He received his Ph.D. and Master degree $\left(1^{\text {st }}\right.$ Class Hons) from the Department of Management Systems at the University of Waikato, New Zealand. His research interests are in the areas of IS alignment, organizational critical activities, ecommerce, interpretive case studies, and supply chain management.

Tsan-Ching Kang is a Ph.D. candidate of the Department of Information Management at National Chung Cheng University in Taiwan. He received his master degree from the same university. His research interests include group communication, virtual community, technology acceptance, and knowledge management.

King-Zoo Tang is a doctoral student of Information Management at National Chung Cheng University in Taiwan. He received his master degree from the same university. His research interests include decision support systems, knowledge management, and electronic commerce. He has published papers in Government Information Quarterly and Journal of International Technology and Information Management. 